MAREK HENDRYKOWSKI

Institute of Film, Media and Audiovisual Arts

Adam Mickiewicz University in Poznań

\title{
The temple of the new faith. Film images of the construction of the Palace of Culture 1952-1955
}

\begin{abstract}
Aвstract. Hendrykowski Marek, The temple of the new faith. Film images of the construction of the Palace of Culture 1952-1955. „Images” vol. XXII, no. 31. Poznań 2017. Adam Mickiewicz University Press. Pp. 39-54. ISSN 1731-450X. DOI 10.14746/i.2017.31.05.

The first study of its kind, Marek Hendrykowski's paper examines frame by frame the symbolic role of the construction of the Palace of Culture in the ideological context of the Stalinist period and its emergence into the realm of public discourse in the early 1950s.
\end{abstract}

KEYwords: Polish cinema, ideology, architecture, socialist realism, stalinism, symbolic dominance

In the heart of Poland, visible from a distance, It will last like faith in a human being, It will last like a child's love, It will last like Soviet friendship.

Jan Brzechwa, Pałac Kultury [The Palace of Culture] [1]

Monument No. 1 - architectural icon of socialist realism in Poland. It was called the "monument to friendship", "Soviet gift", "Stalin's gift", but also "the dream of a crazy confectioner", "Russian fist", "there's no knowing what," "presumed modernity" and "superfluous miracle" (this was Stefan Kisielewski). Tadeusz Konwicki called it the Mała Apokalipsa [A Minor Apocalypse] - "the monument of pride" and "the statue of slavery". The architectural ugliness of the Palace of Culture and Science is contained in the ostentation of its location, the monstrosity of the structure and the excess of all kinds of details and decorations. The absurdity of erecting such a monstrous edifice in this place, above the roofs of Warsaw, is matched by the bizarre ugliness of its eclectic aesthetics.

When the idea of building a monumental memorial to communism on the Vistula was born in the generalissimo's mind (and it is worth recalling that this command was passed on to Polish comrades by no one else but the Minister of Foreign Affairs Vyacheslav Molotov during his visit to Warsaw in July 1951) one thing became absolutely clear to the documentary filmmakers: it necessary to record everything

[1] A poem on the occasion of the decision to build the Palace of Culture and Science [author's translation], 1952. 
related to its construction with a camera: from the first excavation until its completion.

Was everything recorded? Not at all. But what has survived deserves the attention of the researcher. Thousands of metres of film stock about the construction of the Palace of Culture - currently sitting in the Documentary and Feature Film Archive at Chełmska Street - are illustrative material, which is very clear in many respects. Not only what has been recorded on these tapes, but also the things that cannot be seen will be the object of our attention.

It is worth introducing here some important distinctions between the three categories: the first is the facts and events that have not been recorded (for example, that during the construction of the Palace of Culture up to sixteen people died, including fourteen workers and two children on whom the scaffolding fell). The second - still existing film materials that have not been used before (they were not published for various reasons). And the third, the "official" pictures, which after passing the censor and gaining the acceptance of the highest party authorities were shown very widely at that time in documentary films and in the editions of the Polska Kronika Filmowa [Polish Film Chronicle].

All propaganda (and after all it is the category of propaganda messages that is evidently being discussed here) insistently emphasises and shows to the addressee one thing, at the same time eagerly omitting and silencing the other (considered "uncomfortable" by the propagandist, for varying reasons). And years later these silences prove to be as intriguing as the selected images which we see on the screen, and sometimes the former are even much more significant than the latter. This is not only a matter of what was omitted at the stage of editing and was not included in the film, but also the effect of manipulating the message, which distorts certain facts with the intention of imposing the meaning desired by the message conveyor.

Message rhetoric

Well, this is the propaganda of these films. We will be particularly interested in the rhetorical aspect of filming the Palace of Culture: from the moment when it is not there yet, and there is only a decision on its construction (Polish-Soviet agreement signed in Warsaw on April 5,1952 ), until the point at which it is officially put into service (on the so-called Feast of the Rebirth, July 22, 1955). Therefore, in total, it involves a substantial, body of archival film tapes, consisting of several tens of thousands of metres and spanning a period of just over three years. During this time, from month to month, shot after shot and material after material, a certain more and more conventionalized, rigid and repetitive ritualized form of the message is being crystallized, and within its borders there is a permanent repertoire of cinematography tricks, with the help of which the subject is described and mythicized.

The chronological record of the gigantic building being erected in Warsaw remains at all times in the centre of attention of those implementing this record. However, the building itself - as a special 
purpose architectural object, and above all as a higher idea - functions from the very beginning in these messages on the basis of pars pro toto, being a visible testimony to and expression of the unshakeable permanence of the Polish-Soviet friendship, and the benevolence of the leading system, but also the technological superiority of the "elder brother" and, interestingly, also the "elder sister," because in addition to thousands of men, brave women (welders, crane operators and others) also worked on the construction of the Palace of Culture.

Soviet man can. They have already built many such skyscrapers at home. Now the time has come to, at the commander's order, to share the acquired skills and build something to demonstrate to others, to teach the natives new technologies and methods of work ("The Palace of Culture is a construction university for our workers, and for us all a wonderful permanent monument to the Stalinist friendship of nations" - says a comment in the 16/53 edition of the Polska Kronika Filmowa). The new world demands to establish a mythical beginning for itself. There was nothing before it, and even if there was something before, this past - as something that has passed and belongs to the old order - is something inherently worse and no longer necessary.

The historic amnesia, into which they attempted to drive the enslaved society, makes us believe that we will learn everything from scratch from the Russians, as if we had never built anything impressively modern at its time: e.g. Prudential, a pre-war skyscraper at Napoleon modern before this time: e.g. Prudential, the pre-war skyscraper on Napoleon Square, which fell into disrepair after the Warsaw Uprising, protruding over the city like a pathetic stump of defeat, while still maintaining a perfectly designed and executed reinforced concrete skeleton.[2]

Before the Soviet experts entered the construction site to demonstrate the export "show," they had had to live somewhere in the capital. The materials of the Polska Kronika Filmowa of 1952 (item number 6331) contain unused material entitled "Construction of a housing estate at Jelonki for the builders of the Palace of Culture and Science." The camera operator Karol Szczeciński filmed very little at that time: excavations, roof binding and wall alignment. Today, the fact that the Palace of Culture and Science was erected by more than three and a half thousand builders who were had been assigned by Stalin to Warsaw from various parts of the Soviet Union has already grown dim in the collective memory.

To accommodate them, at a pace and in the middle of nowhere in Warsaw's Jelonki, a workers' housing estate was built and called the "Drużba" estate or Friendship estate. A film report on the life of the newly opened estate for the Russians was made in October 1952 by Olgierd Samucewicz. He filmed a pennant for the best-kept room in

[2] It is worth noting that shortly before the war, the Warsaw architect Juliusz Nagórski introduced, in the presence of President Ignacy Mościcki, the project of erecting a two-hundred-metre tall skyscraper equipped with a radio mast at the top. The building was supposed to stand in the vicinity of the Washington Roundabout. 
a workers' hostel, a common room, a reading room, a theatre room, a canteen and a hairdresser (a generic scene of making a permanent wave) among other things.

Soviet engineers, technicians, welders, concreters, bricklayers, fixers, fitters, mechanics, electricians, stonecutters, carpenters, as well as "wierchołazy" (high altitude assembly specialists) - brought with them many years of experience gained before the war and after the war in the construction of socialist realist skyscrapers in Moscow or while finishing the stations of the Moscow underground. They worked with us for long months, in hard and dangerous conditions, which were inseparable from building anything at high altitude. We watch them on the screen, but it is not they who are the most important but rather the results of their work. Filmmakers documented them stage by stage, searching for images that were suggestive in their expression.

The canonical take was usually a panorama of the construction describing the microcosm of the construction, from chaos the new emerges. Camera operator Nikolai Kononov, who worked at that time for Polska Kronika Filmowa, filmed nearly three hundred metres (this is quite a few) in September 1952: the construction site, cavernous excavations, geodesic measurements, welding of steel structures, their general view, cranes in motion, an excavator, close-up of the bucket digging the ground, a crane hook, concrete mixers. In the same month, operator Karol Szczeciński recorded on 210 metres of film tape: the view of the construction, buckets transporting cement, the foundation frame, welding process, cutting steel bars, working cranes and a woman operating a crane. Operator Zdzisław Śluzar, who visited the place with a camera a month later, recorded the construction site, setting up another crane, pitching the foundation, and a strong accent in the form of a close-up of a working construction machine (with an obligatory background in the form of old tenement houses and an occasional addition of a gloomy autumn sky).

The mythology of this great construction "in the heart of the Polish capital" was just beginning to get shape. The poetics of its film images naturally had to be more specific than the lyrical sighs of dozens of poets and panegyrists writing about the "crown of Warsaw," "a palace based on stars", "the gift of the Soviet people for the Polish nation" in literal adulation at its being extraordinary. Documentary filmmakers with a camera needed something specific. However, it was not about the mud in the excavation and the builder's wits, but about the specific, and concrete thing - photogenic, magical, making impression on the viewer.

It was necessary for this purpose to film various attractive realities showing, for example, the immense size of the Soviet building erected in the vicinity of Warsaw's ruins. On the occasion of filming the panorama of the construction and the transportation of steel constructions and reinforced concrete slabs carried by a crane, in October 1952 the Polska Kronika Filmowa operator Władysław Forbert recorded 
priceless documentary material showing the surroundings of the erected Palace, which were soon demolished: old tenement houses and ruins of houses on Marchlewskiego Street (today Jana Pawła II Street), the view of one-storey buildings in Marszałkowska Street, the intersection with Jerozolimskie Avenue, several wide views from above.

The first materials from 1951-1952 are still not very spectacular. It is difficult to admire the work of the excavator, the removal of debris and the view of cavernous foundations. The reference style of pictures typical of the report dominates. They are much more similar to the news reports from Nowa Huta. Film images in the form of prosaic documentary notation (bulldozers, excavators, bursts at excavations, pouring concrete, etc.) record the changes taking place on the construction site more than they excite the viewer. The agitational trance, however, is what characterises the intrusive, off-camera propaganda commentary, read in a sublime way by the then reader of the Chronicle - Andrzej Łapicki.

However, we can already see on the screen and hear off camera the rhetorical game for the high stakes, which was to make the people, tired with indescribably difficult living conditions in ruined Warsaw, accept the unnecessary and costly gift that the dictator from the Kremlin gave to their city.

In the case of the Palace of Culture, an important propaganda role was played by the wooden platform constructed at the very beginning, serving as a makeshift viewing terrace for all who would like to observe the construction work from it. The construction site was visited not only by crowds of ordinary Polish citizens and official delegations, but also by special groups, including trips of participants of the rally of activists of the Polish Youth Union, national Congress of Engineers and Technicians, the Congress of Technical Intelligentsia, etc. The ideological importance of building this edifice was also highlighted by so-called "Bierut watchmen", who helped with some of the work and assisted the builders.

For ordinary residents of Warsaw what happened from 1951 to 1955 in the quadrilateral between Jerozolimskie Avenue, Marszałkowska Street, Świętokrzyska Street and Emilia Plater Street meant bringing and shaping a new order by the communist system. Floor by floor was built by the dictator on the site that had been demolished and captured with violence. One could say he built it on (not) his land. The Palace of Culture and Science was supposed to dominate the city, reminding any opponents and doubters who really governs Poland. Communism, which was embodied in this enormous building, demonstrates its own power, scale and range of possibilities. Cloud-reaching socialist realism was to justify real socialism and render it sublime. Warsaw, like the whole country, was struggling with ruins and rubble. Millions of ordinary citizens in a conquered country, without any help, were trying to resurrect and rebuild their own normal life after the war. In such

Real socialism vs. socialist realism 
a situation, could the totalitarian glitz and splendour, represented by such a gigantic investment, realised without any regard for rationally justified costs, count on collective approval?

Widespread demand for housing (see Skarb [The Treasure] directed by Leonard Buczkowski, 1949) arises to an incredible scale in post-war Poland, causing flats to become the unreal dream of a large number of people. Against the background of the daily hardships and hard-to-manage deficiencies, it is clear that the Palace of Culture and Science is not needed by anyone (except Stalin). And yet, thanks to the collective effort of thousands of workers building it day and night, it will be erected and permanently realized in the capital ruined by the war, regardless of the huge costs, because that is the will of the tyrant.

In addition, another vector was also active in social life. "Poland is fascinated by the rebuilding of Warsaw and the Communists are doing a great job of identifying their actions with the desires of the nation. Certainly, they are right when they say that nobody else would have made such a complex effort in this respect," says Leopold Tyrmand, sharply. [3] However, the construction of housing estates, the W-Z Route or the reconstruction of the Warsaw Old Town are very different from a monstrous palace complex that absorbs enormous material resources.

Domestic propaganda must explain and justify this unnecessary and expensive investment. [4] It is no coincidence that the old Varsovians nicknamed the Palace of Culture and Science "Pekin" (Beijing). "Apart from the anagram [resulting from the Polish acronym for the Palace - PKiN]," writes Tyrmand in his diary, "there is a subtext: such was the name of the large tenancy in pre-war Warsaw, at the corner of Złota and Żelazna, the place for clandestine bawdy houses." [5] Independent of the thousands of articles, construction reports, poems and dithyrambs, the dislike of the "Stalin's gift," whether someone likes it or not, was a psycho-social fact which could not be completely underestimated by propaganda.

Because during a few years, in the Documentary Film Studio at Chełmska Street, nothing could have been more important than recording the subsequent stages of building of the Palace of Culture and Science, it is not surprising that apart from Nowa Huta, the Warsaw Palace of Culture and Science is today the documented building constructed in Poland after the War. Indeed, there is no shortage of material on it. Let us try to study their development in this paper,

[3] L. Tyrmand, Dziennik 1954, Warszawa 1989, quotation p. 213.

[4] The construction of the Palace of Culture, although extremely expensive, was not a one-time and finally closed expense. Another, borne by the society to this day, comprises the significant costs of its main- tenance. It is enough to mention that this colossus's power consumption measured in megawatts can be compared to the demand for a city the size of Ursus, Garwolin or Otwock.

[5] L. Tyrmand, op.cit., pp. 210-211. 
capturing the less clear contextual meanings that have largely lost their clarity since then.

Apparently, this is how the architect Józef Sigalin reacted during the attempts made in 1951 to test the height of the future building. It is not known how much truth lies in this repeated anecdote, but one thing is certain: our architects were stubbornly seeking to increase the Palace's parameters, aiming to make it even higher than its original, the Moscow building of the University of Lomonosov. Today, one might ironically say that they had it their own way.

The new Warsaw on the drawing boards of socialist realism was supposed to resemble Moscow. "In this way, MDM was made, a stone cake, covered with balconies made of boulders, draped with sixteen-metre pillars" - wrote Leopold Tyrmand. And he immediately added with anxiety:

This is probably what will happen to the square around the Soviet skyscraper. The designs at the show exude excessive size and pathos to the power of ten. But why should the plinth and gravity become the emblem and mood of the new Warsaw? Nobody has ever accepted that it must be so in the sacred books of communism. A crowd of people at the design shows testifies to the insatiable hunger for new Warsaw's Athens, the people of the capital yearn for greatness

noted the writer in his diary, before the building was completed and handed over.[6]

The overwhelming, monstrous impression of the Palace results from a series of related determinants of collective perception: political, psychosocial, sociological, urban, architectural and aesthetic. The most important of these is the incredible scale of the investment. Anyone who takes a look at the Warsaw Palace of Culture sees that it cannot be called tiny. "Small but tasteful", the famous French actor Gérard Philipe reportedly said on seeing the Palace during his stay in Warsaw. In another version of this anecdote, the saying "small but tasteful" is sometimes attributed to Antoni Słonimski.

Whoever uttered these three very ironic words, was undoubtedly right. The bright, cream-white colour of the building detached from the background of the surrounding ruins and rubble in an almost ghostly manner, bringing into the city landscape an element of something absolutely surreal, is alien and monstrous at the same time. In order to weaken and neutralize this unfavourable impression, the city authorities decided to fill the Palace's surroundings with rows of perennial trees, creating the substitutes of park architecture at its boundaries, indeed indispensable in every big city. However, this did not help much.

At the time of its completion, in 1955, more than two hundred and thirty metres high at the top of the spire, the edifice was supposedly the tallest building in Europe. But was not about breaking records: it

[6] Ibidem, quotation pp. 214-215. 
was about something else, namely, to demonstrate the steadfast power of the communist regime in the centre of the capital of the conquered country, to give expression to the rule of the new power and to permanently confirm its dominance by building a gigantic monument to communism, which was essentially nothing but a giant temple of the new faith.

The Palace of Culture also fundamentally changed the spatial arrangement of the city. While the longitudinal architectural axis of Warsaw, the Royal Route, has always been obvious, the latitudinal axis of the capital, running from east to west, was moved after the war and fundamentally altered: from the Saxon axis to the axis of Jerozolimskie Avenue. The building of the Central Committee of the Polish United Workers' Party as well as the huge architectural complex of the Palace of Culture and Science were built there. The building, which reached up into the sky, now took on the function of "axis mundi", a centre in which the perspectives and paths of the local world converged. The powerful silhouette of the monstrous Palace, with no regard for any reasonable proportions, was to be visible not only within the city centre, but from anywhere in Warsaw.[7]

\section{A troublesome gift}

To carry out the huge task of designing the architectural complex of the Palace of Culture and Science (mighty foundations, 42 storeys, the spire, Congress Hall, colonnades, a lectern with an honorary grandstand, dozens of stone sculptures in alcoves and on the front facade, two obelisks, $[8]$ a sundial with a man as the shadow, a swimming pool etc.) Stalin delegated his best urban planners and contractors. On July 30 , 1951, his favourite, the chief architect of the Soviet Empire, Lev Rudnev, came to Poland. During a tour around Poland, together with Polish colleagues, expressing admiration of our architecture, he searched for the elements of the national style (Sukiennice, Wawel, Barbakan, City Hall in Zamość, Kazimierz on the Vistula and others) which are to be adapted and used in the project.

In fact, it was only about giving an external impression. Deprived of the native context, the presence of elements of these buildings would be a kind of empty architectural gesture. In the very assumption of the concept, they would play a superficial role, performing the function of decorations and artificial "additions," paradoxically presenting themselves as an alien part of a social realist complex. Incorporated with no composition and order - they look just as exotic as the huge granite statues of Mickiewicz and Copernicus, located in front of the

[7] The chief doctrinaire of socialist realism in Polish architecture, Edmund Goldzamt, aimed further in his vision, designing the eastern axis of the capital so that it would run from the entrance to the Palace of Culture to the river, breaking through partly demolished Nowy Świat and Powiśle. After Stalin's death, in front of the entrance to the Palace, a huge monument to the leader of the world proletariat facing east was to be placed.

[8] Because of historical accuracy, it should be added that a third street obelisk was erected with names and distances to the capitals of Europe carved on it: from Moscow, through Berlin, Paris and London, to Reykjavik. 
main entrance to the Palace, carved by Stanisław Horno-Popławski and Ludwika Nitschowa.

From the very beginning it was a well-known fact that the Palace of Culture is to be "national in form and socialist in content," combining the heavy neoclassicism of socialist realism with shallow and ornamental treatment of local historicism, quite awkwardly modelled on American skyscrapers. This was a cacophony of dissimilar aesthetics and styles that were incompatible. Monumental in design, the architecture of socialist realism was created in the 1930 and widely tested in the Soviet Union. Now it was imposed and practised outside the USSR, and in the Polish export version it aimed to "make familiar" and "make Polish" the foreignness of its own expression through the use of selected "familiar" accessories and the cultural memes that were "friendly" for the natives. The words spoken by Rudnev on this occasion are exceptionally ironic: "We came to the conclusion that this project should aim create a uniform image of beauty that would combine into one architectural whole and be connected with the old Warsaw."

A month after Molotov's visit, in August 1951 the final decision was taken in Moscow to build the Palace of Culture and Science as well as to locate it in the place where it stands today. The leader of Polish socialist realism in architecture, Józef Sigalin, was appointed the plenipotentiary of the construction work. Although he tried to wriggle out of this responsibility, he could not refuse such an honourable distinction, but due to the multitude of other duties (construction of the MDM complex), he appointed his own plenipotentiary to perform this great task - Henryk Janczewski.

A gift is a gift. In the agreement concluded on April 5, 1952, the Soviet authorities declared that the USSR was meeting all the costs of building the Palace. And they were huge in financial as well as in material terms.

The long train is going to Poland,

Big excavators at the very front -

- the poet and propagandist Roman Pisarski obligingly rhymed in an occasional poem entitled Rośnie w Warszawie Pałac Kultury [The Palace of Culture Grows in Warsaw].

The construction foundation itself absorbed more than 3,000 tons of steel and 16,000 tons of concrete. About 11,00o tons of steel were used on the skeleton of the construction structure. Filling in the ceilings and walls was concrete delivered by a crane in five-ton "jugs," thousands of prefabricated reinforced concrete slabs called "pillows" weighing ten tons each, stone blocks and millions of bricks carried on their backs by workers called "koźlarze" (brick carriers). It is enough to mention that the ceramic tiles used to make the façade occupy a total area of over ninety thousand square metres. Not only concrete and bricks, also the material used to finish the monstrous edifice came from Poland. Pińczów limestone, Strzegom granite and Sławniowice marble were selected for this purpose. 
A few more words about the gigantic scale of the entire project. The base of the Palace together with the adjoining areas covers an area of over six hectares. It is more than a quarter of a kilometre long and more than two hundred metres wide. The base of the mighty palace tower, 40 metres high, is made up of a square with with 41-metre sides. From the beginning, the planned size of the huge building evoked the discussions in the team of designers. During his stay in Poland, the main author of the design, Rudnev, during his stay in Poland, suggested that the height of the structure to the roof should not exceed 120 metres. However, Polish architects (probably bearing in mind the Moscow prototype of the University of Lomonosov on the Lenin Hills) opted to raise the height by several dozen metres and this is what finally happened.

More film material comes from the Polska Kronika Filmowa (theme 1 newsreel 17/52). It was filmed by cinematographer Franciszek Fuchs and presents the celebratory moment of signing the agreement between Poland and the Soviet Union on the construction of the Palace of Culture and Science in Warsaw on April 5, 1952. At that time, Prime Minister Józef Cyrankiewicz and ambassador Arkady Sobolev, in the Presidential Palace and in the presence of President Bolesław Bierut, officially signed an agreement in this matter. The contract provided that the Palace was to be built by builders from the USSR. There was no construction design at that moment yet, only the initial idea.

The architectural design was created at Moscow in a truly tireless pace (with the actual participation of our architects and urban planners). Time was short. They worked on it, rushed off their feet. And they had a lot to work on. It is worth realizing that the total area of the complex is over 123 thousand square metres, the cubage - over 800 thousand cubic metres, and in total it contains nearly 3300 rooms.[9] The project documentation was delivered in spring 1952 by rail transport from Moscow in thirty railroad cars and presented on April 18 in the Column Hall of the Palace of Ministers on Krakowskie Przedmieście Street. Three days later, the government's presidium and Bolesław Bierut jointly adopted a resolution to accept the draft design of the Palace.

The ideological offensive in Warsaw grew in strength. While preparing favourable ground for this construction, nothing was forgotten when it comes to the propaganda aspect. There was even a special conference of the representatives of the government and the public with Soviet designers and builders (PKF 19/52). In the film material, standing by the model of the building, one can see such dignitaries as the chief designer of the Palace of Culture and Science, Lev Rudnev, and the deputy Minister of Construction of the USSR Georgy Karavayev. On the occasion, Rudnev made the following remarkable statement: "This building seems to vanish in the air, like the singing of Ewa Bandrowska-Turska, from the silence goes into the highest crystalline sounds, so

[9] On the opening day, July 22, 1955, a significantly smaller number of 2,300 ready-to-use rooms were made available. Many others were bricked up at the time of incomplete interiors. Still others (several inaccessible special-purpose storeys) were permanently excluded from public use. 
here too, in the construction of this building, we must strive to create the lightness of form, the magnificence of the form of the building under construction at the transition from the monumental lower parts."

By force of the lie then told and later repeated, the Palace of Culture had already become "light" before it was erected. On the May Day parade of 1952, the residents of Warsaw could see a huge model of the future Palace filmed by the Chronicle operators and included in the next special issue (PKF 20/52), in which the first footage of the construction work, which began symbolically on May 1, 1952, were also shown. We have a compulsory panorama of foundation digging, then the silhouettes of Soviet excavators and the model of the Palace. A powerful bulldozer called "Stalin" prepares debris for the excavator which loads it onto trucks. Subsequent shots show the demolition team and the work of the excavator operator.

From the anthropological point of view, the Palace of Culture as a temple of communism - fulfils most of the conditions necessary to recognize it as an edifice subjected by its creators to the ritual of socialist realist consecration from the very beginning. For the builders it was to be a special place, everlasting, visited by millions of believers of the new faith. We have here both the symbolism of the "centre of our world" and the designation of the "holy area", separated from the sea of post-war ruins and rubble. By rebuilding the destroyed Warsaw, the Communists revived it, appropriating it at the same time and usurping the right to create their own reality, of which the Palace was the most striking expression.

It had something of a neo-Gothic tower of Babel about it, whose construction and sky-high dimensions that reach for the sky constitute a visible manifestation of human usurpation and pride. For this reason, as an act of re-creation, this complex had to contain a comprehensive description of the totalitarian cosmos that it invoked. And it actually did contain it. Today, the vast majority of visitors cannot read the meanings of the allegorical architectural program of the Palace of Culture and Science, especially regarding the interpretation of sculptures and reliefs (one not very visible above the main entrance, the other on the way to the Congress Hall entitled "Peace bringing life to people").

They are figures, sculptures, statues, monuments devoid of their own meaning. Meanwhile, in dozens of niches and pedestals, figures were placed on the rights of the emblematic representation of communist society: a builder, a mechanic, a road worker, a kolkhoz woman, a Soviet youth, a miner, a discus thrower, a shot putter, an archer, a man with a bearing, residents of Africa and Central Asia, residents of China and Arabia, a Soviet intellectual, a young man with a volume of Marxist-Leninist classics and a woman with a stylus. We also have sculptures-personifications related to Greek antiquity: literature, theatre, music, poetry, sculpture, dance, love poetry, etc.

\section{Palace of Culture as a temple of the new faith}


Idolatry underlies the countless great constructions of communism. It is equipped with the legitimacy of a new, the only righteous faith. A characteristic determinant of the Palace of Culture and Science in Warsaw is the gradual consecration of this object. By force, documentary filmmakers also took part in it. This is felt very clearly in the ritualistic behaviours of the authority representatives filmed in the material "Laying the Cornerstone for the Palace of Culture and Science" (theme 1, PKF 33/52) from July 1952. The tributary ritual of taking over the "gift of friendship" shown on the screen resembles the local priests and believers taking over a precious relic. Who could have supposed that the process of sacralisation of the building had just begun?

On March 7, 1953, two days after the commander's death, the Council of State and the Council of Ministers of the Polish People's Republic adopted a resolution to give the Palace of Culture the name of Joseph Stalin. Almost immediately, in the double edition of the Polska Kronika Filmowa (PKF 11-12/53), a series of pictures devoted to this issue appears. "The Palace of Culture and Science will be known by the name of Stalin, the gift of the Soviet Union for the capital of Poland," Andrzej Łapicki reads in a sad voice. "The construction site fell silent. Soviet friends! Your pain is our pain. March 9, ten o'clock."

Shortly thereafter, other material was shot for the Polska Kronika Filmowa entitled: “Growing Joseph Stalin's Palace." It shows once again the moment when on March 9, all traffic on the construction site comes to a halt. A lowered reader's voice, this time with an elegiac tone, announces off-camera: "A year ago there was emptiness, and today the construction of the Stalin's Palace of Culture and Science is reaching the 1oth floor." And further, with actor's excitation, Łapicki recites the words of Brzechwa's poem from a year before:

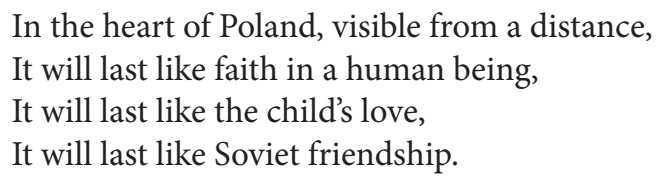

In the same spirit, but in the quite different serene emotional aura characteristic of the Thaw period, one can interpret the solemn scene of handing the Palace of Culture and Science over to the Polish Society two years later, on July 22, 1955. Making an act of cutting the ribbon with the USSR ambassador Panteleimon Ponomarenko, the Prime Minister of the Polish People's Republic celebrates the moment for a long time in order to cut out a fragment for himself and the guest, as a souvenir, and then puts it with devotion into his buttonhole.

The camera accompanies the officials invited to the ceremony in their visit to the interior of the Palace. The real takeover of this place by society, its specific naturalization, is just about to take place. Until 1989, this process would only be substitutive. The Palace of Culture and Science, despite all forms of its everyday and festive utility, would be familiar not only to Varsovians, but in fact would remain eccentrically 
foreign in the city's organism. The more the Palace shone, the more it became sombre and dark in its expression. Orwellian dimension of this building carried something mysterious and inscrutable from the beginning. It made the Palace intriguing also for foreigners.

The psychosocial problem with the Palace of Culture and the "trouble" which this place entailed for decades is due to the tabooing that it had previously been subjected to. The candelabra publicity of what is available to the public has its other side in the form of various dark stories and legends about the underground, secret passages, strange institutions and inaccessible interiors. For decades, this evil spell was attempted by writers, visual artists and filmmakers, among them Tadeusz Konwicki, Stanisław Tym, Andrzej Czeczot, Andrzej Dudziński, Małgorzata Potocka, Wojciech Wójcik, Janusz Zaorski, Andrzej Bart, Borys Lankosz and Magdalena Tulli.

Not only the labyrinthine underground, but also some of the aboveground elements of the building contain the tempting reflection of the demonic power of Stalinism. The constructing and mounting the spire at the very top of the Palace of Culture and Science as the effective crowning was a particularly spectacular feat of the Soviet builders and it was impressive at that time. The Palace of Friendship was called by the poet a "miracle of life leaning on the stars," and according to the intent of the main designer, "the building in its top part seems to vanish in the air."

The spire was supposed to give this impression. Its huge multi-ton construction was pulled to the top of the building with cranes and lifts in the first week of November 1953. To this day, the risky method of its assembly, including the antenna bracket, compels admiration. It was recorded on film in two pieces of material by the fearless Polska Kronika Filmowa operator, Karol Szczeciński. In the first of these pieces (Iglica w górę! [Spire up!], PKF 47/53) the operator's reflection appears in a mirror surface[10] of a large, two-ton sphere which is part of the spire. No wonder that the closing shot of the second material titled Na szczycie pałacu [At the top of the Palace] is accompanied by the following off-camera commentary: "The luminous outline of the building, which was not here a year ago, dominates over the night panorama of Warsaw."

Looking at Defilad Square, we are not aware that its vast space for the Palace was created as a result of large-scale barbaric demolitions of entire streets and quarters of the city centre that had been densely built-up before the war. "The roller will come and make it even..." It

[10] To cover the Palace's spire structure, 1,400 golden mirror plates were used to give it a distinctive colour. The assembly, in line with the commitment made by the builders, was completed a day before the 36 th anniversary of the October Revolution in the presence of Bierut, Zawadzki and Rokossowski. In addition to the materials of the Polish Film Chronicle, a scientific film was made by Jan Jacoby about the assembly of the spire. 
is enough to mention that Wielka Street disappeared from the map of today's Warsaw, and the compact space and transport system composed of several others (Chmielna, Złota, Sienna, Śliska, Zielna, Pańska) was brutally torn apart. The number of houses and tenement houses (some of which were a war ruin, but a significant part, almost one third of the preserved substance, survived intact, the others were damaged but rebuildable despite the damage) supposedly numbered over 160 !

These demolitions were shown briefly and minimally in the Polska Kronika Filmowa in the material Rośnie Pałac Kultury [The Palace of Culture is Growing] (PKF newsreel 33/52) with the following off-camera commentary: "In the centre of Warsaw, on the vast area designated for the construction of the Palace of Culture and Science, the last traces of the wars and ruins are disappearing, the remains of the old destroyed centre of the capitalist Warsaw." In this material, the viewer's attention is drawn by characteristic collision - presented in one take by the operator of the new (impressive silhouette of the erected palace in the foreground) in an intense contrast with the old (grey ruins of old tenement houses visible in the background).

A few years passed, and some of the buildings, which had not been pulled down immediately, were still standing during the construction of the Palace. The last ones were demolished as late as the winter and spring of 1955, shortly before its completion. No one filmed this for obvious reasons. The "new" was no longer something absolutely and indisputably better than the "old," which had been despised so far. Single-storey Marszałkowska Street with its small restaurants and bars, hundreds of shops and a network of service outlets survived in the shadow of the communist temple for long decades. The real size of the social cost of building the Palace of Culture was soon shown by Jerzy Bossak and Jarosław Brzozowski in the famous film from the "black series" of the Polish documentaries Warszawa 1956 [Warsaw 1956].[11]

Imposed by the Communists through symbolic violence, the "religious" experience of a special place, such as the Palace of Culture and Science, after 1955 (or more precisely from the memorable 5th World Festival of Youth and Students, which took place in August 1955 in Warsaw) contrasted with the process of its naturalization, aimed at restoring this structure to various useful forms of everyday life. We have been dealing with the results and effects of this process practically up to the present day. The more there are practical applications of the architectural substance of the Palace experienced in various forms by the society there are, thefewer the associations with the totalitarian ideology that once brought it into existence.

Documentary materials dedicated to the construction of the Palace of Culture were not just the chronicle record of its creation. All of them, more or less, served to create the myth of this building, giving it the presumed propaganda value of uniqueness and unusualness. From

[11] See M. Jazdon, Czarne filmy posiwiały. "Czarna seria" polskiego dokumentu, in: Widziane po latach: analizy i interpretacje filmu polskiego, ed. M. Hendrykowska, Poznań 2000, pp. 55-59. 
Stalin's death, this aspect temporarily acquired much more intense and expressive features, making the edifice a communist temple bearing the name of the commander. Its forced sacralisation, which we have already talked about, fortunately lasted for a short time.

Let us distinguish two useful terms for our use: tabooing and sacralisation. Both concepts seem synonymous. However, they differ from each other in that the tabooing demarcates and expels the object, making it inaccessible to the profane, while sacralisation leads to the elevation of a given place. The cultural familiarisation of the Palace of Culture contains its de-sacralisation (de-consecration), which took place relatively quickly in the mid-fifties, and at the same time its de-tabooing that gradually took place over several decades.

The de-tabooing of this place was not a one-off act; it was slow and gradual. First, when in 1956 the Palace of Culture ceased to be named after Stalin, and the name of Stalin was removed from the stone book with the names of the Marxist-Leninist classics held by the sculpted figure of the agitator. Then, during a huge demonstration at Defilad Square in October 1956, when countless crowds expected from Władysław Gomułka a clear and explicit political declaration about the future of the country, and the sculptures and candelabra in front of the Palace served people climbing up to see and hear better.

The rest was added by life. The ironic grimace of history is expressed not only by the disappearance of Stalin's name on the aforementioned monument and its name engraved on the pediment above the main entrance being covered, but also through a long series of other unimaginable manifestations of de-tabooing this place. These include, among other things, regular theatrical striptease performances in the communist den of sin of the Kongresowa Restaurant, the memorable concert by The Rolling Stones in 1967, and, in the post-breakthrough period, the huge Eastern European bazaar near the place where the monstrous monument of Stalin was supposed to stand, and the popular Tavern "Pod Trybuną" located under the altar of communism, namely a huge stone lectern performing during the May Day parade the function of the grandstand of honour.

The communist authorities voluntarily committed a kind of ideological seppuku when agreeing that on June 14, 1987 at the end of the next pilgrimage to Poland, Pope John Paul II would deliver a homily there on Defilad Square in front of the former temple of communism. During this homily, famous words referring to the biblical trope of the Tower of Babel were spoken: "Created in the image and likeness of God, man assumed that he could be a god to himself." Only two and a half years later, on January 29, 1990, while closing the last PZPR [Polish United Workers' Party] congress, which took place in the Kongresowa Hall, Mieczysław Rakowski ordered: "The flag of the Polish United Workers' Party - move out."

The Palace of Culture and Science became a relic of Stalinist times from a provocative gift an increasingly distant reminder of the 
decades of Polish enslavement by Soviet and native communism. The film images shot during the construction of this building today constitute an irreplaceable testimony to the pride of the enforced system that prematurely announced its triumph. The palace, which is monstrous in its enormity, has become yet another monument to the history of Warsaw, inscribed in the city's landscape and serving its inhabitants. The seductive evil with which it will be associated forever has ceased to exert its evil influence.

Eliade M., Sacrum - mit - historia. Wybór esejów, transl. by A. Tatarkiewicz. Warszawa 1970

Huml I., Pałac w guście epoki, "Renowacje i Zabytki” 2005, no. 3

Minorski J., Oblicze współczesnej polskiej twórczości architektonicznej, in: O polska architekturę socrealistyczną. Materiały z krajowej partyjnej narady architektów odbytej w dniach 20-21 czerwca 1949 roku w Warszawie, Warszawa 1950

Ortega y Gasset J., Dehumanizacja sztuki i inne eseje, transl. by P. Niklewicz. Warszawa 1980

Wolski T., Pałac Kultury primabalerina Warszawy. Rozmowa Tadeusza Sobolewskiego z reżyserem, "Gazeta Wyborcza” 2012, 2 May

Zwierzchowski P., Pęknięty monolit. Konteksty polskiego kina socrealistycznego, Bydgoszcz 2006 